
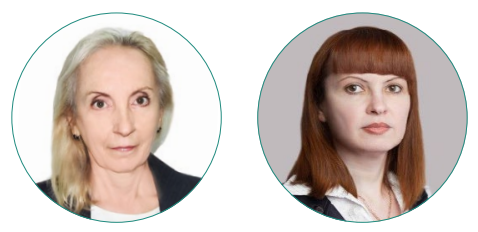

Н. Ю. Танющева, Н. Н. Куницына

\title{
ОЦЕНКА ОБЩЕСТВЕННОГО МНЕНИЯ О СОБЛЮДЕНИИ АНТИОТМЫВОЧНОГО ЗАКОНОДАТЕЛЬСТВА В РОССИИ
}

\section{Правильная ссылка на статью:}

Танющева Н. Ю., Куницына Н.Н. Оценка общественного мнения о соблюдении антиотмывочного законодательства в России // Мониторинг общественного мнения: экономические и социальные перемены. 2021. № 2. С. 213-233. https://doi.org/10.14515/ monitoring.2021.2.1730.

\section{For citation:}

Tanyushcheva N. Y., Kunitsyna N. N. (2021) Assessment of Public Opinion on Compliance with Anti-Cleaning Legislation. Monitoring of Public Opinion: Economic and Social Changes. No. 2. P. 213-233. https://doi.org/10.14515/monitoring.2021.2.1730. (In Russ.) 
ОЦЕНКА ОБЩЕСТВЕННОГО МНЕНИЯ О СОБЛЮДЕНИИ АНТИОТМЫВОЧНОГО ЗАКОНОДАТЕЛЬСТВА В РОССИИ

ТАНЮЩЕВА Наталия Юрьевна - кандидат экономических наук, доцент кафедры мировой экономики и финансов, Астраханский государственный университет, Астрахань, Россия E-MAIL: n.tanyushcheva@yandex.ru https://orcid.org/0000-0002-7277-7316

КУНИЦЫНА Наталья Николаевна доктор экономических наук, профессор, заведующий кафедрой финансов и кредита, Северо-Кавказский федеральный университет, Ставрополь, Россия E-MAIL: natkun2004@mail.ru http://orcid.org/0000-0001-9336-8100

Аннотация. Соблюдение законодательства в целом и Федерального закона "О противодействии легализации (отмыванию) доходов, полученных преступным путем, и финансированию терроризма" (ПОД/ФТ) в частности гражданская обязанность населения и должностных лиц. Вместе с тем информация о его нарушениях довольно часто транслируется в средствах массовой информации и на интернет-ресурсах. В этой связи авторы преследовали цель изучить ценностные установки специалистов по отношению к закону о ПОД/ ФТ, а также оценить эффективность надзорно-контрольной деятельности по его соблюдению путем социологического опроса. Состав участников сформирован методом многоступенчатой выборки. Результаты анкетирования обработаны с помощью адаптированной методики Table of Eleven (T11), основанной на концепции рационального выбора, теории обоснованных действий и нормативной теории права.
ASSESSMENT OF PUBLIC OPINION ON COMPLIANCE WITH ANTI-CLEANING LEGISLATION

Nataliia Yu. TANYUSHCHEVA ${ }^{1}$ - Cand. Sci. (Econ.), Associate Professor, Department of World Economy and Finance E-MAIL: n.tanyushcheva@yandex.ru https://orcid.org/0000-0002-7277-7316

Natalia N. KUNITSYNA² - Prof. Dr. habil. (Econ.), Head of the Department of Finance and Credit

E-MAIL: natkun2004@mail.ru http://orcid.org/0000-0001-9336-8100

${ }^{1}$ Astrakhan State University, Astrakhan, Russia

2 North Caucasus Federal University, Stavropol', Russia

Abstract. Compliance with legislation in general and the Federal Law "On Combating Legalization (Laundering) of Criminally Obtained Incomes and Financing of Terrorism" (AML/CFT) in particular, is a civic duty of the population and officials. At the same time, the media and Internet resources inform about its violation quite often. In this regard, the authors aimed to study the specialists' value attitudes in relation to the AML/CFT law. For this purpose, a sociological survey was conducted on a multistage sample. The results were processed utilizing the adapted Table of Eleven (T11) methodology, based on the concept of rational choice, the theory of justified actions and the normative theory of law.

To study the factors that affect compliance with the anti-money laundering law, the authors summarized and analyzed the opinions of the special officials of commercial banks, the AML / CFT specialists of the Central Bank of the Rus- 
Исследование факторов, влияющих на соблюдение антиотмывочного закона, осуществлено посредством обобщения и анализа мнений специальных должностных лиц (СДЛ) коммерческих банков, специалистов в области ПоД/ ФТ Центрального банка РФ, сотрудников подразделений по борьбе с экономической и организованной преступностью правоохранительных органов. Результаты исследования свидетельствуют, что государственная антиотмывочная политика находит отклик у СДЛ, сам закон понятен исполнителям, однако организация контроля над банками, реализация санкций по отношению к нарушителям и безучастность населения и бизнес-сообщества В информационном взаимодействии с контролирующими органами не способствуют полноценному соблюдению положений антиотмывочного законодательства. Существенному улучшению среды реализации закона призваны способствовать меры по развитию общей солидарности в обществе и расширению программ финансовой грамотности среди предпринимателей.

Ключевые слова: антиотмывочная система, методика Table of Eleven, анкетирование должностных лиц, санкции за правонарушения, отмывание денег

Благодарность. Исследование выполнено при финансовой поддержке РФФИ в рамках научного проекта № 20-010-00243. sian Federation, and the employees of units for combating economic and organized crime of law enforcement agencies. The results of the study indicate that the state anti-money laundering policy resonates with the special officials, the law itself is clear and understandable to the executors. However, control over banks, sanctions against violators and the indifference of the population and the business community in information interaction with regulatory authorities do not contribute to full compliance with the provisions of anti-money laundering legislation. Measures for the development of general solidarity in society and the expansion of financial literacy programs among entrepreneurs are called upon to significantly improve the environment for the implementation of the law.

Keywords: anti-laundering system, Table of Eleven methodology, survey of officials, sanctions for offenses, money laundering

Acknowledgments. The reported study was funded by RFBR, project number 20-010-00243.

\section{Введение}

По итогам четвертого раунда взаимных проверок по оценке эффективности национальных антиотмывочных систем, который Россия прошла в 2019 г., FATF ${ }^{1}$

\footnotetext{
${ }^{1}$ FATF-Группа разработки финансовых мер по борьбе с отмыванием денег (Financial Action Task Force).
} 
не выявлено существенных недостатков. Однако ущерб от экономических преступлений в стране продолжает расти. В этой связи несомненный интерес представляет оценка результативности антиотмывочных процедур.

Система противодействия отмыванию преступных доходов, финансированию терроризма и распространения оружия массового уничтожения (ПОД/ФТ/ФРОМУ) в России представляет собой трехкомпонентную модель. Во-первых, специальные должностные лица (СДЛ) финансовых и иных регулируемых организаций анализируют сделки клиентов и передают сведения о сомнительных операциях или операциях обязательного контроля в Росфинмониторинг. Во-вторых, осуществляются надзор и контроль, применяются санкции к финансовым и иным регулируемым организациям, не соблюдающим антиотмывочные требования. Надзорно-контрольные процедуры и санкционные функции в отношении финансовых организаций выполняет Центральный банк РФ, в отношении иных регулируемых организаций - Роскомнадзор, Пробирная палата, Росфинмониторинг. В-третьих, Росфинмониторинг анализирует информацию о фактах, с высокой долей вероятности указывающих на ОД/ФТ/ФРОМУ², и передает ее в правоохранительные, налоговые, таможенные и иные органы, имеющие право на их расследование.

Целью исследования, основные материалы которого изложены в статье, стало выявление современных тенденций в стимулировании специальных должностных лиц кредитных организаций, ответственных за реализацию требований по ПОД/ ФТ/ФРОМУ, что предопределило необходимость: а) интервьюирования сотрудников Центрального банка РФ (ЦБ РФ) и специалистов подразделений по борьбе с экономической и организованной преступностью правоохранительных органов о поведении СДЛ при исполнении законодательства, а также самих СДЛ; б) выявления основных тенденций стимулирования СДЛ к соблюдению Федерального закона "О противодействии легализации (отмыванию) доходов, полученных преступным путем, и финансированию терроризма" (далее-Закон) и формулирования рекомендаций по повышению результативности антиотмывочных процедур.

\section{Методология}

Методологической основой исследования стала адаптированная к сфере ПОД/ФТ/ФРОМУ методика комплексной оценки действенности законодательства - тест T11 (Table of Eleven). Методика T11 разработана Д. Руимшотелем, П. Рииненом, Х. Клаасеном [Ruimschotel, Van Reenen, Klaasen, 1996] на основе сочетания концепции рационального выбора Г. Беккера [Becker, 1968], теории обоснованных действий Фишбейна-Айзена [Fishbein, Ajzen, 1975] и нормативного подхода в исследовании стимулов законопослушания [Glos, 1969]. Методика предполагает исследование одиннадцати групп факторов, обусловливающих три составляющие правоприменения:

1) воспринимаемость профессиональным сообществом в сфере ПОД/ФТ/ ФРОМУ конкретного закона (насколько понятен текст закона; издержки и выгоды, связанные с соблюдением и несоблюдением закона);

\footnotetext{
2 Здесь и далее по тексту ОД/ФТ/ФРОМУ - отмывание преступных доходов, финансирование терроризма и финансирование распространения оружия массового уничтожения. В России эти виды преступной деятельности регулируются Федеральным законом от 07.08.2001 г. № 115-Ф3 «0 противодействии легализации (отмыванию) доходов, полученных преступным путем, и финансированию терроризма». ПоД-противодействие отмыванию доходов.
} 
2) ценностные установки по отношению к нему и к законам в целом (приемлемость положений закона; общее уважение к законодательству и властям; присутствие негосударственного контроля; добровольное соблюдение закона под влиянием различных факторов, либо под угрозой наказания);

3) организацию надзорно-контрольной деятельности за его соблюдением (плотность (частота проверок), глубина (вероятность обнаружения нарушений) и целенаправленность контроля; вероятность наказания и его суровость).

В идеале закон должен быть понятен, а его цели, задачи и инструменты должны находить отклик у граждан и официальных лиц, исполняющих его без принуждения. На случай умышленного нарушения закона в нем оговорены санкции, предупреждающие неисполнение.

Критики методики Т11, например Х. Эльферс и др., утверждают, что это не готовый, полностью стандартизованный инструмент, а комплекс идей, используемых для приведения в соответствие известных факторов законопослушания [Elfers, van der Heijden, Hezemans, 2003]. По мнению Ф. Хэмптона, "Т11 - это грубый инструмент, но он структурирует мышление регулирующих органов и может направлять их в те области, которые требуют особой поддержки и в которых компании вряд ли захотят нарушать правила" [Hampton, 2005: 57]. Данный аргумент предопределил логику и последовательность исследования, в основу которого положено анкетирование специалистов, чья деятельность связана с соблюдением антиотмывочного законодательства или контролем за его исполнением.

Методика Т11 создавалась как структурированный опрос экспертов в области применения законодательства в той или иной сфере. Законы, регулирующие отношения в большинстве секторов экономики, содержат нормы наиболее общего характера, детализируемые в технических стандартах и ведомственных нормативных документах. Однако в сфере ПОД/ФТ/ФРОМУ как исполнители, так и контролеры имеют дело с самим законодательным актом и применяют его в своей ежедневной практике, что позволяет в рамках методики Т11 рассматривать их в качестве экспертов.

Каждый из трех компонентов национальной антиотмывочной системы представлен в опросе особой группой экспертов: 1) надзорно-контрольные органы (специалисты по финансовому мониторингу региональных отделений Центрального банка РФ); 2) правоохранительные органы (сотрудники отделов региональных подразделений МВД России по борьбе с экономической и организованной преступностью); 3) СДЛ (специалисты и руководители подразделений по финансовому мониторингу коммерческих банков). В стране действует единая законодательно-нормативная база по ПОД/ФТ/ФРОМУ; стандартные требования к квалификации и зоне ответственности СДЛ; унифицированный механизм трансмиссии антиотмывочных знаний, включающий в себя централизованную систему повышения квалификации специалистов Центрального банка, которые затем участвуют в обучении СдЛ коммерческих банков в форме семинаров (вебинаров).

Учитывая однородность генеральной совокупности, выборка была сформирована серийным (гнездовым) методом. В опросе приняли участие 358 респондентов, работающих в организациях и учреждениях Ставропольского, Краснодарского краев, Астраханской, Волгоградской, Саратовской областей, Карачаево-Черкесской 
и Кабардино-Балкарской республик (92 сотрудника Центрального банка, 78 работников правоохранительных органов и 188 СДЛ). Опрос проводился путем анонимного анкетирования по 44 вопросам (их перечень приведен в Приложении), сгруппированным в три блока: 1) воспринимаемость закона о ПОД/ФТ/ФРОМУ, 2) эффективность ценностных установок по отношению к нему и 3) эффективность надзорноконтрольной деятельности за его соблюдением. Часть переменных предполагала выбор оценки в диапазоне от 00 до 10 (10 означает стопроцентную вероятность влияния фактора), другая часть была ориентирована на однозначный ответ: "нет" (1 балл), "затрудняюсь ответить" (2 балла) или "да» (3 балла). Прямое направление признака (более высокие оценки соответствуют наиболее благоприятной оценке), в том числе в отношении ответов "нет»/ «затрудняюсь ответить"/"да", позволило представить в численных показателях суммарную оценку стимуляции к соблюдению антиотмывочного законодательства в России разными группами экспертов.

Инструменты, оцениваемые по десятибалльной шкале, имеют определенную гибкость корректировки (факторы гибкой настойки). Вопросы с ответами "да/нет" ориентированы на оценку факторов, не поддающихся гибкому регулированию (факторы прямого воздействия).

Ценностные установки по отношению к Закону и законодательству в целом работают методом прямого воздействия. Это касается мнения респондентов о наличии/отсутствии выгоды или потерь от соблюдения/несоблюдения законов, собственной заинтересованности в их исполнении, своевременности и целесообразности государственной антиотмывочной политики, негосударственных форм антиотмывочного контроля, лояльности населения и бизнеса к проверкам. Положительные, отрицательные или нейтральные ответы в таком случае свидетельствуют о действенности того или иного фактора на законопослушание в сфере ПОД/ФТ/ФРОМУ. Что касается вопросов о степени воздействия выгод, преимуществ либо ущерба на соблюдение Закона, то ответы с десятибалльной шкалой позволили выявить потребность в подстройке уже действующих механизмов антиотмывочного регулирования. Вопросы, посвященные оценке качества надзорно-контрольной деятельности за соблюдением антиотмывочного законодательства, ориентированы на выявление действенности санкционных мер в ходе развития антиотмывочного движения.

Подготовка к опросу 2020 г. началась в феврале. Ограничения, введенные в стране в связи с распространением COVID-19, привели к изменению организации процесса. Если ранее анкеты передавались одновременно группе респондентов - сотрудников коллектива, то в период локдауна и перевода части сотрудников на удаленную работу переписка велась по большей части индивидуально. В результате рассылка анкет, их сбор и обработка заняли три месяца. Вместе с тем, несмотря на изменившиеся условия, опрошенные сохраняли профессиональный энтузиазм и отмечали важность освещаемой опросом тематики.

\section{Результаты}

Результаты обобщения собранных по методике Т11 данных (см. Приложение) обнажили ряд проблем (см. рис. 1 и 2). Авторское видение их истоков и рекомендации по нейтрализации негативного фона в общественном мнении мы приводим ниже. 
1) Как показал опрос, респондентам понятны область применения Закона, объекты и субъекты надзора и контроля. Документ не перегружен деталями, содержит общие и главные предписания. Высокая оценка документа отдает должное многолетней целенаправленной работе законодателей по его корректировке (более семидесяти изменений почти за 20 лет действия Закона).
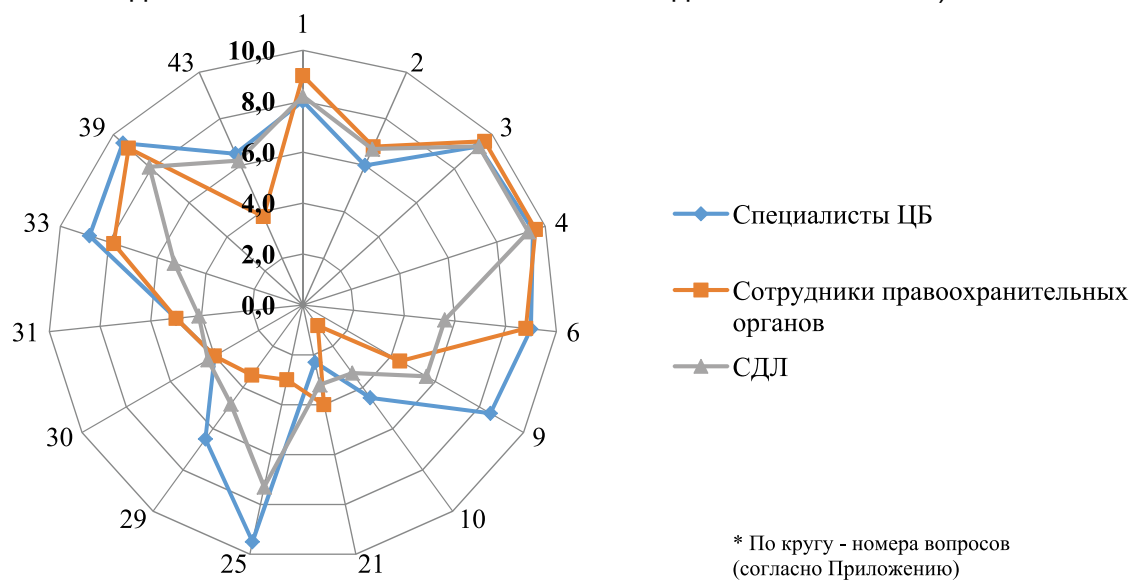

Рис. 1. Количественные параметры стимуляции законопослушания в сфере ПОД/ФТ/ФРОМУ (факторы прямого воздействия, баллы)

2) Все респонденты считают государственную политику в сфере ПОД/ФТ/ФРОМУ целесообразной, способы ее реализации - приемлемыми. Они чувствуют собственную ответственность за претворение этой политики в жизнь (в качестве примечания некоторые указали профессиональную ответственность), уважение к Закону и личный интерес в его соблюдении (связанный с профессией). Этот аспект российского антиотмывочного закона также можно оценить как достаточно стимулирующий.
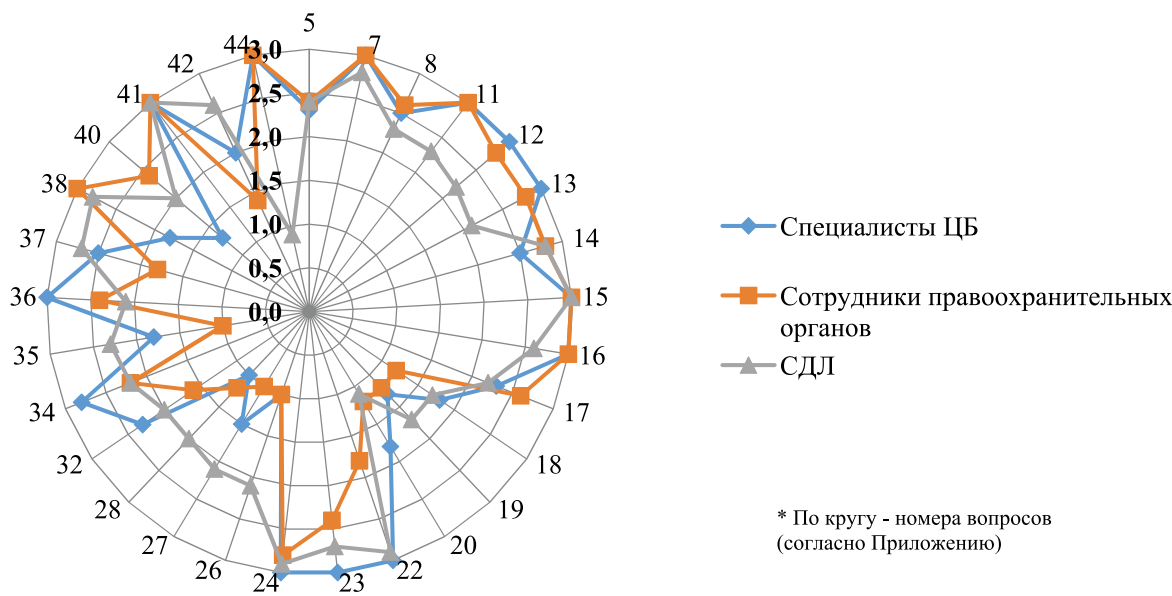

Рис. 2. Количественные параметры стимуляции законопослушания в сфере пОД/ФТ/ФРОМУ (факторы гибкой настройки, баллы) 
3) Соотношение стимулов исполнения антиотмывочного законодательства, рассчитанных по группам респондентов (см. табл. 1), свидетельствует, что СДЛ в среднем констатируют меньше стимулов к соблюдению антиотмывочного закона, чем правоохранительные и надзорно-регулирующие органы.

Таблица 1. Уровень стимуляции к соблюдению антиотмывочного законодательства в России (2020 г.)

\begin{tabular}{|c|c|c|c|c|c|c|}
\hline \multirow[t]{2}{*}{ Показатель уровня стимуляции } & \multicolumn{2}{|c|}{$\begin{array}{l}\text { Специалисты } \\
\text { цБ }\end{array}$} & \multicolumn{2}{|c|}{$\begin{array}{c}\text { Сотрудники } \\
\text { правоохранит. } \\
\text { органов }\end{array}$} & \multicolumn{2}{|c|}{ сдл } \\
\hline & баллы* & $\%$ & баллы* & $\%$ & баллы* & $\%$ \\
\hline Соблюдение & 121,5 & 89 & 98,1 & 81 & 115,4 & 98 \\
\hline $\begin{array}{l}\text { В том числе высокая степень соблюде- } \\
\text { ния (ответы со значениями } 7 \text { баллов } \\
\text { и выше либо "да") }\end{array}$ & 95,0 & 70 & 73,5 & 61 & 73,0 & 62 \\
\hline $\begin{array}{l}\text { Несоблюдение (ответы со значениями } \\
\text { ниже } 3 \text { баллов или «нет») }\end{array}$ & 14,5 & 11 & 22,6 & 19 & 2,3 & 2 \\
\hline Нейтральный ответ «0» & 0,5 & 0 & 0,4 & 0 & 0,00 & 0 \\
\hline Итого & 175,4 & 100 & 167,4 & 100 & 157,8 & 100 \\
\hline
\end{tabular}

* Показатель “баллы” сформирован суммированием средних арифметических оценок ответов соответствующих групп респондентов (см. Приложение).

4) Последовательный рост оптимизма по большинству аспектов антиотмывочной законопослушности, зафиксированный группами специалистов по ПОД/ФТ/ФРОМУ ЦБ РФ и работников правоохранительных органов, не соответствует показателям эффективности российской антиотмывочной системы, рассчитанным на основе статистических данных ЦБ РФ, Росфинмониторинга и МВД России (см. табл. 2).

Таблица 2. Эффективность антиотмывочной системы России в 2014-2018 гг.*

\begin{tabular}{|c|c|c|c|c|c|c|}
\hline \multirow{2}{*}{ Показатель } & \multicolumn{6}{|c|}{ Год } \\
\hline & 2014 & 2015 & 2016 & 2017 & 2018 & 2019 \\
\hline $\begin{array}{l}\text { 1) Количество сведений об операциях, } \\
\text { представленных в Росфинмониторинг } \\
\text { в соответствии с антиотмывочным зако- } \\
\text { нодательством (в млн ед.) }\end{array}$ & 12,63 & 22,15 & 30,02 & 33,77 & 29,25 & 27,53 \\
\hline $\begin{array}{l}\text { 2) Выявлено преступлений легализации } \\
\text { (отмывания) денежных средств или } \\
\text { иного имущества, приобретенных лицом } \\
\text { в результате совершения им преступле- } \\
\text { ния либо приобретенных другими лица- } \\
\text { ми преступным путем (в ед.) }\end{array}$ & 774 & 863 & 818 & 711 & 993 & 946 \\
\hline $\begin{array}{l}\text { 3) Выявлено лиц, уголовные дела о кото- } \\
\text { рых направлены в суд, либо привлечено } \\
\text { к уголовной ответственности лиц, совер- } \\
\text { шивших преступления легализации (от- } \\
\text { мывания) денежных средств или иного } \\
\text { имущества, приобретенных лицом в ре- } \\
\text { зультате совершения им преступления }\end{array}$ & 448 & 592 & 596 & 530 & 619 & 624 \\
\hline
\end{tabular}




\begin{tabular}{|c|c|c|c|c|c|c|}
\hline \multirow{2}{*}{ Показатель } & \multicolumn{6}{|c|}{ Год } \\
\hline & 2014 & 2015 & 2016 & 2017 & 2018 & 2019 \\
\hline $\begin{array}{l}\text { 4) Качество сведений о легализации (от- } \\
\text { мывания) денежных средств или иного } \\
\text { имущества, приобретенных лицом в ре- } \\
\text { зультате совершения им преступления } \\
\text { либо приобретенных другими лицами } \\
\text { преступным путем, на одно выявленное } \\
\text { такое преступление** }\end{array}$ & 16317 & 25666 & 36699 & 47496 & 29456 & 29133 \\
\hline $\begin{array}{l}\text { 5) Эффективность следственной работы } \\
\text { в отношении материалов, поступивших } \\
\text { в Росфинмониторинг и переданных } \\
\text { в следственные органы } * * *\end{array}$ & 0,58 & 0,69 & 0,73 & 0,75 & 0,62 & 0,66 \\
\hline $\begin{array}{l}\text { 6) Количество банков, прекративших } \\
\text { свою деятельность в результате отзыва } \\
\text { лицензии, в т. ч. по причине неоднократ- } \\
\text { ного нарушения в течение одного года } \\
\text { требований антиотмывочного закона }\end{array}$ & $\begin{array}{l}87 \\
68\end{array}$ & $\begin{array}{l}90 \\
66\end{array}$ & $\begin{array}{l}97 \\
40\end{array}$ & $\begin{array}{l}49 \\
24\end{array}$ & $\begin{array}{l}57 \\
33\end{array}$ & $\begin{array}{l}27 \\
11\end{array}$ \\
\hline
\end{tabular}

* Источники: Anti-Money Laundering and Counter-Terrorist Financing Measures - Russian Federation (Fourth Round Mutual Evaluation Report) / FATF. 2019. December. P. 54. URL: https://www.fatf-gafi.org/media/fatf/documents/ reports/mer4/Mutual-Evaluation-Russian-Federation-2019.pdf (дата обращения: 14.04.2021); Состояние преступности в России / МВД РФ. URL: https://xn--b1aew.xn--p1ai/reports/2/ (дата обращения: 14.04.2021); Вестник Банка России за 2014-2019 гг. URL: https://www.cbr.ru/about_br/publ/vestnik/year/2021/ (дата обращения: 14.04.2021).

** Количество сведений, представленных в Росфинмониторинг в соответствии с антиотмывочным законодательством, на одно выявленное преступление легализации (отмывания) денежных средств или иного имущества, приобретенных лицом в результате совершения им преступления либо приобретенных другими лицами преступным путем.

*** Количество лиц, уголовные дела о которых направлены в суд, либо привлечение к уголовной ответственности лиц, совершивших преступления по легализации (отмыванию) денежных средств или иного имущества, приобретенных в результате совершения им преступления либо приобретенных другими лицами преступным путем, на одно выявленное преступлений легализации (отмывания) денежных средств или иного имущества, приобретенных лицом в результате совершения им преступления либо приобретенных другими лицами преступным путем.

Как видно из таблицы 2, в 2014-2019 гг. в России было отозвано 407 банковских лицензий, из них 242 - за несоблюдение антиотмывочного закона. Однако только по пяти уголовным делам руководители банков либо лица, их контролирующие, осуждены за преступления, связанные с отмыванием денег³. При этом по данным Росфинмониторинга лишь в 2018 г. в крупных российских банках были ликвидированы 27 площадок по отмыванию денег в общей сумме более 244 млрд руб.

Подугрозой санкций финансовые и иные регулируемые в целях ПОД/ФТ/ФРОМУ организации формируют внутреннюю антиотмывочную политику, адекватную рискам в данной сфере. Политика включает в себя процедуры обучения и переобучения персонала с целью формирования высоких этических и профессиональных стандартов и назначение квалифицированных СДЛ, ответственных за корректировку и практическую реализацию риск-ориентированного подхода внутри финансовой организации. Соблюдение СДЛ антиотмывочного законодательства стимулировано, с одной стороны, финансовой организацией-работодателем (вы-

\footnotetext{
3 Информация о привлечении к уголовной ответственности лиц, контролировавших кредитные организации, признанные несостоятельными (банкротами) за период с 2005 г. по 01.04.2021 г. Агентство по страхованию вкладов. URL: https://www.asv.org.ru/about/liquidation (дата обращения: 27.04.2021).
} 
сокая зарплата, подчиненность непосредственно руководителю организации и т. п.), с другой стороны - органами власти (угроза штрафа, дисквалификации, ограничения на определенные должности в финансовых организациях). В странах с рыночной экономикой эти стимулы объясняются теориями, основанными на интересах и знаниях, и постулатами теории рационального выбора.

Поскольку правоохранительные органы в большей мере используют принудительные инструменты, эффективность антиотмывочного инструментария, расширяющего информационное поле для расследований предикатных преступлений, доходы от которых попали в круг антиотмывочных процедур, положительно оценивается сотрудниками правоохраны. Невысокая численность лиц, привлеченных к ответственности непосредственно за отмывание денег, как показал опрос, связана со сложностью доказательства таких преступлений. Суровость административных и регуляторных мер, которые применяет ЦБ РФ к финансовым организациям, не соблюдающим антиотмывочное законодательство, не является полноценной компенсацией уголовному преследованию. В результате, с одной стороны, не соблюдается принцип "преступление - наказание" в отношении сотрудников финансовых организаций, вовлеченных в отмывание денег, с другойдобросовестные сотрудники лишаются работы, а их финансовые и карьерные перспективы серьезно ухудшаются.

5) Скептицизм респондентов группы СДЛ по подавляющему большинству аспектов российского антиотмывочного законодательства в 2020 г. достаточно высок. Масштабный отзыв лицензий у банков негативно сказывается не только на клиентах, но и на сотрудниках, испытывающих трудности с восстановлением своей деловой репутации. Отсутствие детальной информации о причинах отзыва банковских лицензий, о результатах расследований и именах виновных в вовлечение финансовой организации в отмывание денег, повлекшее за собой прекращение ее деятельности, дезориентирует специалистов в сфере ПОД/ФТ/ ФРОМУ в вопросах государственной антиотмывочной политики, Закона, его инструментария и системы наказаний.

6) Участники опроса по-разному оценивают результативность материальных, моральных и социальных стимулов, встроенных в Закон для его исполнения. Все группы респондентов отметили, что соблюдение Закона требует значительного количества денег, времени и усилий, но экономические потери от нарушений оказываются выше. Современные финансовые институты осознают фатальные риски [Kunitsyna, Sitnikova, 2016], которым подвергают себя нарушители Закона, и воспринимают затраты на организацию и осуществление антиотмывочных мер как объективную необходимость. Вместе с тем усложнение антиотмывочных требований ведет к увеличению затрат преступников на их преодоление как в виде растущих банковских комиссий на высокорискованные виды операций, например обналичивание, так и на гонорары финансовых консультантов, разрабатывающих схемы отмывания преступных доходов [Баранов, 2017: 389]. Таким образом, все группы опрошенных единодушны во мнении, что Закон содержит в себе экономические, моральные и социальные стимулы к его исполнению. Однако отношение к результативности таких стимулов во всех группах разное. Вера в высокую стимулирующую способность экономической, моральной и социальной 
выгоды от соблюдения антиотмывочного закона заметно снижается от группы "специалисты ЦБ" к группам "сотрудники правоохранительных органов" и "СДЛ". Непосредственные исполнители видят меньше стимулов для соблюдения Закона, чем регулятор и правоохрана.

7) Наряду с сильными сторонами Закона, стимулирующими его соблюдение, опрос по методике Т11 выявил и недостатки в его применении. Например, единодушное отрицание респондентами всех целевых групп во всех исследованиях (2008, 2012, 2017, 2020 гг.) склонности населения и руководителей предприятий ставить в известность контролирующие органы при обнаружении правонарушения в сфере ПОД/ФТ/ФРОМУ и отсутствие осведомленности, какому контролирующему органу следует сообщать об этом, отражают ситуацию с общим дефицитом информационного обмена между обществом и контролирующими органами в России. В литературе данное явление связывают с кризисом социального доверия [Зубок, Чупров, 2017] и социальным равнодушием на постсоветском пространстве, при сущим всем индустриальным обществам в целом [Родионова, 2017]. Участники опроса 2020 г. отметили, что в исполнении антиотмывочного закона заинтересованы исключительно профессионально (материально). Достичь позитивных перемен в сложившейся ситуации в рамках лишь антиотмывочной политики невозможно. В последние годы правительство приступило к скоординированным государственным и общественным усилиям для достижения общей солидарности.

Изменение общественного сознания - задача стратегическая, долговременная. Но для гибкой корректировки антиотмывочной системы и ее элементов многоканальный механизм обмена оперативной информацией о ее функционировании необходим уже сегодня. В этой ситуации определенный прогресс должна принести проработка вопросов ПОД/ФТ/ФРОМУ в рамках общенационального движения по повышению финансовой грамотности, предусмотренная Концепцией развития национальной системы противодействия легализации (отмыванию) доходов, полученных преступным путем, и финансированию терроризма, задача которой - не допустить вовлечение предпринимателей в совершение незаконных финансовых операций ${ }^{4}$.

8) Впервые в подобных опросах в 2020 г. обозначилась проблема получения ущерба финансовыми организациями от соблюдений закона о ПОД/ФТ/ФРОМУ. В опросах 2008, 2012, 2019 гг. [Танющева, 2009; 2012; 2019] речь шла об ущербе для нарушителей, что логично. В комментариях к соответствующему вопросу (см. Приложение, вопрос 20) в 2020 г. специалисты ЦБ РФ и СДЛ впервые указали на существующую напряженность в отношениях банков и клиентов по поводу непроведения платежей или отказа в открытии счета в рамках антиотмывочных процедур, которая не только создает препятствия бизнес-процессам, но и негативно сказывается на деловой репутации банков. Несмотря на корректировку в 2018 г. законодательства в сторону создания механизма реабилитации клиентов и формирование Межведомственной комиссии при ЦБ РФ по этому вопросу, ограничения платежей продолжают нарастать. Наряду с фирмами-однодневками, для

\footnotetext{
4 Концепция развития национальной системы противодействия легализации (отмыванию) доходов, полученных преступным путем, и финансированию терроризма (утв. Президентом РФ 30.05.2018) / URL: http://www.kremlin. ru/supplement/5310 (дата обращения: 14.04.2021).
} 
сокращения активности которых этот механизм был включен в антиотмывочные процедуры, под действие Закона попадают компании, функционирующие в "серой" зоне частично: субъекты среднего, малого и микробизнеса, индивидуальные предприниматели, которые не разделяют личные деньги и деньги компании. Половина отказов в проведении платежей происходит по вине самих бизнесменов (неуплата налогов в срок, нарушение правил сдачи деклараций, ошибки в платежных документах и др. $)^{5}$.

9) Поскольку контроль - неотъемлемая часть эффективности исполнения любой нормы, отдельная группа вопросов (вопросы 29-39, см. Приложение) касалась проверок, которые позволяют не только оперативно оценивать ситуацию с соблюдением Закона, но и выполняют профилактическую функцию, стимулируя законопослушание. Однако применительно к сфере ПОД/ФТ/ФРОМУ опрос выявил невысокую профилактическую значимость проверок. Вероятность ежегодных документальных проверок специалисты ЦБ РФ оценили в 6,5 балла из 10, СДЛ - 4,8, сотрудники правоохраны - 3,4. Еще ниже оказались оценки вероятности инспекций на местах. Полученный результат можно объяснить масштабным переходом контрольных процедур из выездного формата в удаленный, что подтверждается оценками респондентов вероятности обнаружения нарушений в сфере ПОД/ФТ/ФРОМУ при дистанционных проверках (8,8 баллов - специалисты ЦБ РФ; 7,8 - сотрудники правоохранительных органов и 5,3-СДЛ). В целом опрошенные считают техническое обеспечение инспекторов достаточным и уверены в их способности находить правонарушения по ПОД/ФТ/ФРОМУ. Участники групп “специалисты ЦБ” и “сотрудники правоохранительных органов" однозначно подтвердили свое уважение к праву контролирующих органов на проверки, тогда как четверть опрошенных СДЛ с ними не согласилась. Первые две группы считают проверочную деятельность эффективным звеном правоприменительного механизма по ПОД/ФТ/ФРОМУ, однако СДЛ их мнение не разделяют. Можно предположить, что неудовлетворенность результатами дистанционной надзорно-контролирующей деятельности за исполнением финансовыми организациями требований антиотмывочного законодательства сохраняет у Банка России и правоохранительных органов потребность в инспекционных проверках, с чем не согласны добросовестные СДЛ, расценивающие их как излишнюю нагрузку.

10) Широкий разброс мнений зафиксирован по поводу наличия каких-либо ограничений по месту и/или времени применения антиотмывочного законодательства. Правоохранительные органы и часть сотрудников ЦБ РФ ответили на соответствующий вопрос (см. Приложение, вопрос 35) отрицательно, СДЛ и отдельные респонденты из отделений ЦБ - положительно. К местам, где существует ограничение на применение антиотмывочного законодательства, участники опроса отнесли страны со льготным режимом налогообложения и маскировкой информации о бенефициарных владельцах. Несмотря на последовательную политику FATF по углублению имплементации требований о прозрачности финансовых операций, практики в области ПОД/ФТ/ФРОМУ все еще констатируют существенные пробелы в реализации антиотмывочных стандартов в ряде стран.

\footnotetext{
5 Агеева О. Блокировка счетов привела к остановке половины компаний МСП//РБК. Экономика. 2019.17 мая. https://www.rbc.ru/economics/17/05/2019/5cdda1b39a7947267df714ab (дата обращения: 25.04.2021).
} 
11) Все опрошенные единодушно подтвердили, что знают, какие формы наказаний применяются к нарушителям Закона. Вероятность санкций в случае обнаружения правонарушения в сфере ПОД/ФТ/ФРОМУ респонденты считают высокой (8,1-9,5 баллов из 10), они также видят дополнительные прямые и косвенные неудобства для нарушителей Закона. Неоднозначность в ответах проявилась при оценке действенности антиотмывочных санкций (специалисты ЦБ и СДЛ не считают их суровыми, а сотрудники правоохранительных органов отметили затянутость их исполнения). Следовательно, действующие санкции не в полной мере способствуют соблюдению антиотмывочного законодательства.

12) Особого внимания, по нашему мнению, заслуживают ответы на вопрос о доказательности правонарушений в сфере ПОД/ФТ/ФРОМУ (см. Приложение, вопрос 40). Сотрудники подразделений по борьбе с экономическими преступлениями и СДЛ считают, что доказать такие правонарушения легко. Их позиция не согласуется с официальной статистикой раскрываемости преступлений в сфере ПОД/ФТ/ФРОМУ в России и с мировой практикой в целом, а также не подтверждается динамикой ущерба от экономических преступлений (см. рис. 3).

500000000 450000000 400000000 350000000 300000000 250000000 200000000 150000000 100000000 50000000

0

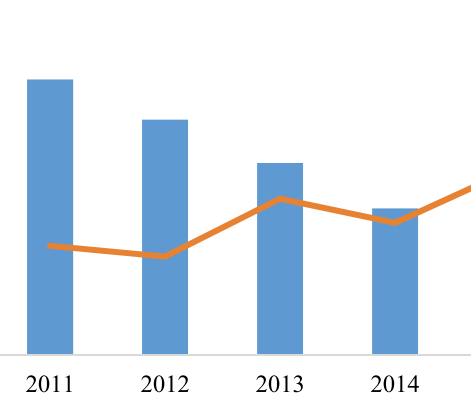

2014

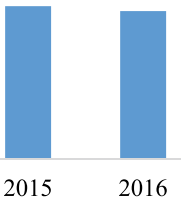

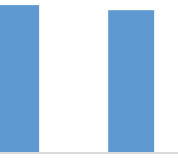

2017
250000

200000

150000

100000

50000

0

$2018 \quad 2019$

Количество экономических преступлений, ед.

Ущерб от экономических преступлений, тыс. руб.

Рис. З. Динамика экономической преступности и ущерба от экономических преступлений в России в 2011-2019 гг. ${ }^{6}$

Проверки четвертого раунда состояния антиотмывочных систем стран Большой двадцатки, объединяющих крупнейшие национальные экономики и финансовые системы, показали основную проблему роста эффективности антиотмывочного движения: наработанная информация используется для расследования предикатных преступлений, но не тех, что связанны с ОД/ФТ/ФРОМУ. Факты отмывания денег выявляются при расследовании самих предикатных преступлений и из иных источников, таких как человеческие ресурсы (информаторы, жертвы, подозреваемые и т. п.), разведывательные данные, и, в меньшей степени, в результате упреждающего раскрытия информации национальными подразделениями финансовой разведки либо других правительственных ведомств, не имеющих полномочий

${ }_{6}^{6}$ Источник: Состояние преступности // МВД России. URL: https://мВд.рф/folder/101762 (дата обращения: 14.04.2021). 
на проведение расследований в сфере ПОД/ФТ/ФРОМУ 7 . Объясняется это тем, что преступные доходы формируются в результате предикатного преступления, объем которого определяется в ходе расследования и предъявляется для компенсации виновным. Выделить ущерб непосредственно от отмывания преступного дохода зачастую невозможно, поэтому сложно соотнести затраты правоохранительных органов и экономический эффект от раскрытия преступлений. Решение вопроса ответственности за добросовестное исполнение антиотмывочных требований финансовыми организациями и их должностными лицами в России введено в функционал Банка России в рамках административного правоприменения. В арсенале главного финансового регулятора страны находятся такие меры, как отзыв лицензии на финансовую деятельность, штраф, решение о несоответствии квалификации или деловой репутации членов органов управления, должностных лиц и собственников финансовых организаций.

\section{Заключение}

Проведенное исследование позволило выявить как сильные стороны российского антиотмывочного закона, так и его узкие места. Обобщив мнения респондентов, можно сделать вывод, что понятный, не перегруженный деталями, но содержащий все основные и важные аспекты текст Закона способствует его соблюдению, при этом государственная политика в сфере ПОД/ФТ/ФРОМУ находит отклик у ее исполнителей.

Результаты анкетирования свидетельствуют о разбросе мнений экспертов относительно воздействия на соблюдение антиотмывочного законодательства различных факторов. Специалисты ЦБ РФ и сотрудники правоохранительных органов считают проверки сильным стимулом правоприменения, однако это мнение не разделяют СДЛ. Последние также не согласны с респондентами из надзорных и правоохранительных органов по поводу профилактической роли санкций при соблюдении законодательства. Административные меры как основной карательный инструмент не заменяют детальное, всестороннее уголовное расследование. Неумышленные ошибки СДЛ наказываются штрафами, потерей репутации, трудностями с карьерой и дальнейшим трудоустройством. При этом из-за сложностей с доказательной базой и приоритетной сосредоточенностью правоохранительных органов на предикатных преступлениях в условиях ограниченных ресурсов виновным в отмывании преступных доходов лицам часто удается уклониться от ответственности.

Опрос выявил еще одну слабую сторону практической реализации антиотмывочного законодательства в России, а именно, отсутствие склонности населения и бизнес-сообщества сообщать контролирующим органам о нарушениях в сфере ПОД/ФТ/ФРОМУ, а также неосведомленности, куда именно следует обращаться в таких случаях.

Сопоставление результатов опроса 2020 г. с предыдущими демонстрирует определенные изменения в исследуемой сфере. Например, в 2009 г. экспер-

\footnotetext{
7 Anti-Money Laundering and Counter-Terrorist Financing Measures. Canada (Mutual Evaluation Report) / FATF. APG. 2016. September. URL: http://www.fatf-gafi.org/media/fatf/documents/reports/mer4/mer-canada-2016.pdf (дата обращения: 14.04.2021).
} 
ты правоохранительных органов отметили, что не понимают методов, которыми действует антиотмывочный закон, однако позднее именно представители правоохраны стали наиболее уверенными его сторонниками. В опросах 2009, 2012, 2017 гг. респонденты высказывались за более высокую эффективность проверок на местах, тогда как из ответов на вопрос о дистанционных проверках (см. Приложение, вопрос 33), впервые поднятый в 2020 г., следует изменение мнения экспертов в пользу современных надзорных технологий. Налицо рост квалификации специалистов и осознание преимуществ использования достижений технического прогресса в антиотмывочной сфере. Вместе с тем главные недостатки в реализации антиотмывочного закона остались неизменными. Это, во-первых, невысокая численность лиц, привлеченных к ответственности за отмывание преступных доходов, в сравнении с масштабом антиотмывочного движения; и, во-вторых, индифферентность общества к фактам несоблюдения Закона.

Полагаем, что антиотмывочные программы финансовой грамотности для предпринимателей как на этапе регистрации собственного дела (в обязательном порядке), так и в ходе работы уже действующего бизнеса (добровольно), помогут сформировать в деловом сообществе правильное понимание природы антиотмывочной системы и выработать модель добросовестной, социально ответственной деятельности.

\section{Список литературы (References)}

Баранов П. А. Обналичивание денежных средств: налоговая оптимизация или преступление? // Современный ученый. 2017. № 5. C. 388-391. URL: http:// su-journal.ru/archives/10052 (дата обращения; 25.04.2021).

Baranov P. A. (2017) Cashing out: Tax Optimization or a Crime? Modern Scientist. No. 5. P. 388-391. URL: http://su-journal.ru/archives/10052 (accessed: 25.04.2021). (In Russ.)

Родионова О.В. Солидарность общества как базовый принцип государства в контексте новых реалий / / Вестник Московского университета МВД. 2017. № 3. C. $111-116$.

Rodionova O.V. (2017) Social Solidarity as a Basic Principle of the Social State in the Context of New Realities. Bulletin of the Moscow University of the Ministry of Internal Affairs. No. 3. P. 111-116. (In Russ.)

Танющева Н. Ю. Исследование применения законодательства в области противодействия (отмывания) доходов, полученных преступным путем // Деньги и кредит. 2009. № 9. C. 29-33. URL: https://rjmf.econs.online/archive/2009/9/? PAGE=1 (дата обращения; 25.04.2021).

Tanyushcheva N. Yu. (2009) Study of the Application of Legislation in the Field of Countering the Legalization (Laundering) Of Income Received Criminal Way. Russian Journal of Money \& Finance. No. 9. P. 29-33. URL: https://rjmf.econs.online/archive/2009/9/? PAGE=1 (accessed: 25.04.2021). (In Russ.)

Танющева Н. Ю. Противодействие отмыванию теневых капиталов в России: эффективность регулирования // Финансовая аналитика: проблемы и решения. 
2012. T. 5. Вып. 41. С. 33-42. URL: https://www.fin-izdat.ru/journal/fa/detail.php? $\mathrm{ID}=53558$ (дата обращения: 25.04.2021).

Tanjushcheva N. U. (2012) Anti-Money Laundering in Russia: Efficiency of Regulation. Financial Analytics: Science and Experience. Vol. 5. No. 41. P. 33-42. URL: https:// www.fin-izdat.ru/journal/fa/detail.php? ID=53558 (accessed: 25.04.2021). (In Russ.)

Танющева Н. Ю. Эффективность национального противолегализационного регулирования: эмпирическое исследование на примере России // Вопросы экономики. 2019. № 8. C. 139-144. https://doi.org/10.32609/0042-8736-2019-8-139-144. Tanyushcheva N. Yu. (2019) The Effectiveness of National Anti-Money Laundering Regulation: An Empirical Study on the Example of Russia. Voprosy ekonomiki. No. 8. P. 133-144. https://doi.org/10.32609/0042-8736-2019-8-139-144. (In Russ.)

Зубок Ю. А., Чупров В.И. Угрозы В трансформирующейся среде обитания как фактор социальных рисков: прогнозирование и регулирование // Социологические исследования. 2017. № 5. C. 57-67. URL: https://www.isras.ru/index.php?page_id =2624\&jn=socis\&jn=socis\&jid=6686 (дата обращения: 25.04.2021).

Zubok Yu.A., Chuprov V.I. (2017) Threats in a Transforming Living Environment as a Factor of Social Risks: Forecasting and Regulation. Sociological Studies. No. 5. P. 57-67. URL: https://www.isras.ru/index.php?page_id=2624\&jn=socis\&jn=socis\&jid=6686 (accessed: 25.04 .2021$)$. (In Russ.)

Becker G.S. (1968) Crime and Punishment: An Economic Approach. Journal of Political Economy. Vol. 76. No. 2. P. 169-217. https://doi.org/10.1086/259394.

Fishbein M., Ajzen I. (1975) Belief, Attitude, Intention and Behavior: An Introduction to Theory and Research. Reading, MA: Addison-Wesley.

Glos G. E. (1969) The Normative Theory of Law. William \& Mary Law Review. Vol. 11. No. 1. P. 151-184. URL: https://scholarship.law.wm.edu/cgi/viewcontent.cgi?article $=2772 \&$ context $=$ wmlr (accessed: 25.04.2021).

Hampton P. (2005) Reducing Administrative Burdens: Effective Inspection and Enforcement. London: HM Treasury.

Kunitsyna N. N., Sitnikova E. V. (2016) Currency Risks Hedging of Commercial Banks' Corporate Clients. Journal of Internet Banking and Commerce. Journal of Internet Banking and Commerce. Vol. 21. No. 3. S6. URL: https://www.icommercecentral. com/open-access/currency-risks-hedging-of-commercial-banks-corporate-clients. php?aid=82670 (accessed: 28.04.2021).

Ruimschotel D., Van Reenen P., Klaasen H. M. (1996) De Tafel-van-Elf. The Table-ofEleven. Beleidsanalyse. No. 3. P. 4-13. 


\section{Приложение}

Таблица. Перечень вопросов анкеты и обобщение результатов опроса*

\begin{tabular}{|c|c|c|c|c|c|c|c|}
\hline \multirow[b]{2}{*}{ № } & \multirow[b]{2}{*}{ Переменные } & \multicolumn{2}{|c|}{$\begin{array}{l}\text { Специалисты ЦБ } \\
\text { РФ }\end{array}$} & \multicolumn{2}{|c|}{$\begin{array}{c}\text { Сотрудники } \\
\text { правоохранит. } \\
\text { органов }\end{array}$} & \multicolumn{2}{|c|}{ сдл } \\
\hline & & 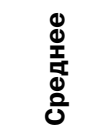 & $\begin{array}{l}5 \\
5 \\
5 \\
\dot{5}\end{array}$ & 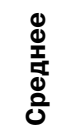 & $\begin{array}{l}5 \\
5 \\
5 \\
5\end{array}$ & $\begin{array}{l}\frac{1}{1} \\
\frac{1}{5} \\
\frac{0}{0}\end{array}$ & \begin{tabular}{l}
$\dot{5}$ \\
\multicolumn{2}{c}{} \\
$\dot{5}$ \\
$\dot{U}$
\end{tabular} \\
\hline I & \multicolumn{7}{|c|}{ Воспринимаемость закона о ПОД/ФТ/ФРОМУ } \\
\hline 1 & $\begin{array}{l}\text { Насколько хорошо Вы } \\
\text { знаете закон о ПОД/ФТ }\end{array}$ & 8,0 & 1,414 & 9,0 & 2,236 & 8,2 & 1,716 \\
\hline 2 & $\begin{array}{l}\text { Насколько детально, } \\
\text { по Вашему мнению, разра- } \\
\text { ботан закон о ПоД/ФТ }\end{array}$ & 6,0 & 0,000 & 6,8 & 1,095 & 6,7 & 1,414 \\
\hline 3 & $\begin{array}{l}\text { Насколько понятны для } \\
\text { Вас объекты и субъекты, } \\
\text { к которым применим за- } \\
\text { кон о ПОД/ФТ }\end{array}$ & 9,3 & 0,957 & 9,6 & 0,894 & 9,3 & 1,000 \\
\hline 4 & $\begin{array}{l}\text { Насколько понятна для } \\
\text { Вас область применения } \\
\text { закона о пОД/ФТ }\end{array}$ & 9,5 & 0,577 & 9,6 & 0,894 & 9,3 & 1,014 \\
\hline II & \multicolumn{7}{|c|}{$\begin{array}{l}\text { Эффективность ценностных установок по отношению к закону о ПОД/ФТ/ФРОМУ } \\
\text { и законам в целом }\end{array}$} \\
\hline 5 & $\begin{array}{l}\text { Согласны ли Вы, что со- } \\
\text { блюдение закона о ПоД/ } \\
\text { ФТ требует меньшего } \\
\text { количества денег, вре- } \\
\text { мени и усилий, чем его } \\
\text { нарушение }\end{array}$ & 2,3 & 0,957 & 2,4 & 0,894 & 2,4 & 0,707 \\
\hline 6 & $\begin{array}{l}\text { По Вашему мнению, со- } \\
\text { блюдение закона о поД/ } \\
\text { ФТ имеет какие-либо } \\
\text { преимущества (в деньгах, } \\
\text { времени, усилиях) по срав- } \\
\text { нению с его нарушением }\end{array}$ & 9,0 & 1,414 & 8,8 & 1,304 & 5,6 & 3,500 \\
\hline 7 & $\begin{array}{l}\text { По Вашему мнению, на- } \\
\text { рушение закона о ПоД/ } \\
\text { ФТ влечет за собой } \\
\text { какие-либо отрицательные } \\
\text { последствия (потери) эко- } \\
\text { номического характера }\end{array}$ & 3,0 & 0,000 & 3,0 & 0,000 & 2,8 & 0,667 \\
\hline 8 & $\begin{array}{l}\text { По Вашему мнению, со- } \\
\text { блюдение закона о ПоД/ } \\
\text { ФТ имеет какие-либо } \\
\text { выгоды экономического } \\
\text { характера }\end{array}$ & 2,5 & 1,000 & 2,6 & 0,894 & 2,3 & 0,866 \\
\hline
\end{tabular}




\begin{tabular}{|c|c|c|c|c|c|c|c|}
\hline \multirow{2}{*}{ № } & \multirow{2}{*}{ Переменные } & \multicolumn{2}{|c|}{$\begin{array}{c}\text { Специалисты ЦБ } \\
\text { РФ }\end{array}$} & \multicolumn{2}{|c|}{$\begin{array}{l}\text { Сотрудники } \\
\text { правоохранит. } \\
\text { органов }\end{array}$} & \multicolumn{2}{|c|}{ сдл } \\
\hline & & $\begin{array}{l}\frac{0}{0} \\
\frac{1}{1} \\
\frac{1}{0} \\
\frac{0}{0}\end{array}$ & $\begin{array}{l}\dot{5} \\
\text { s. } \\
\dot{5} \\
\dot{5}\end{array}$ & 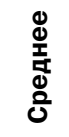 & $\begin{array}{l}\dot{5} \\
\text { s. } \\
\dot{5} \\
\dot{5}\end{array}$ & 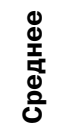 & \begin{tabular}{l}
$\dot{5}$ \\
\multicolumn{2}{c}{} \\
$\dot{5}$ \\
$\dot{5}$
\end{tabular} \\
\hline 9 & $\begin{array}{l}\text { Может ли, по Вашему } \\
\text { мнению, соблюдение за- } \\
\text { кона о ПОД/ФТ принести } \\
\text { какие-либо моральные или } \\
\text { социальные выгоды }\end{array}$ & 8,5 & 1,000 & 4,4 & 3,362 & 5,6 & 3,432 \\
\hline 10 & $\begin{array}{l}\text { Может ли, по Вашему } \\
\text { мнению, соблюдение } \\
\text { закона о поД/ФТ нанести } \\
\text { какой-либо моральный или } \\
\text { социальный ущерб (напри- } \\
\text { мер, имиджу финансовой } \\
\text { организации/компании }\end{array}$ & 4,5 & 4,123 & 1,0 & 0,707 & 3,3 & 2,804 \\
\hline 11 & $\begin{array}{l}\text { Считаете ли Вы принятую } \\
\text { в стране антиотмывочную } \\
\text { политику и ее цели умест- } \\
\text { ными и целесообразными }\end{array}$ & 3,0 & 0,000 & 3,0 & 0,000 & 2,3 & 1,000 \\
\hline 12 & $\begin{array}{l}\text { Считаете ли Вы себя } \\
\text { ответственным(ой) за пре- } \\
\text { творение антиотмывочной } \\
\text { политики в жизнь }\end{array}$ & 3,0 & 0,000 & 2,8 & 0,447 & 2,2 & 0,972 \\
\hline 13 & $\begin{array}{l}\text { Считаете ли Вы приемле- } \\
\text { мыми способы реализации } \\
\text { антиотмывочной политики } \\
\text { в нашей стране }\end{array}$ & 3,0 & 0,000 & 2,8 & 0,447 & 2,1 & 0,782 \\
\hline 14 & $\begin{array}{l}\text { В целом, Вы вынуждены } \\
\text { мириться с законом } \\
\text { о пОД/ФТ }\end{array}$ & 2,5 & 1,000 & 2,8 & 0,447 & 2,8 & 0,667 \\
\hline 15 & $\begin{array}{l}\text { В целом, Вы имеете уваже- } \\
\text { ние к закону о ПоД/ФТ }\end{array}$ & 3,0 & 0,000 & 3,0 & 0,000 & 3,0 & 0,000 \\
\hline 16 & $\begin{array}{l}\text { В целом, Вы уважаете } \\
\text { право контролирующих } \\
\text { органов на проверки }\end{array}$ & 3,0 & 0,000 & 3,0 & 0,000 & 2,6 & 0,882 \\
\hline 17 & $\begin{array}{l}\text { Имеете ли Вы собствен- } \\
\text { ный интерес в отношении } \\
\text { соблюдения закона о ПоД/ } \\
\text { ФТ }\end{array}$ & 2,3 & 0,957 & 2,6 & 0,894 & 2,2 & 0,972 \\
\hline 18 & $\begin{array}{l}\text { Осознаете ли Вы, что } \\
\text { любое нарушение в сфере } \\
\text { ПОД/ФТ будет замечено } \\
\text { населением }\end{array}$ & 1,8 & 0,957 & 1,2 & 0,447 & 1,7 & 0,866 \\
\hline 19 & $\begin{array}{l}\text { Как Вы считаете, в целом, } \\
\text { население одобряет такие } \\
\text { правонарушения }\end{array}$ & 1,3 & 0,500 & 1,2 & 0,447 & 1,7 & 0,707 \\
\hline
\end{tabular}




\begin{tabular}{|c|c|c|c|c|c|c|c|}
\hline \multirow{2}{*}{ № } & \multirow{2}{*}{ Переменные } & \multicolumn{2}{|c|}{$\begin{array}{c}\text { Специалисты ЦБ } \\
\text { РФ }\end{array}$} & \multicolumn{2}{|c|}{$\begin{array}{c}\text { Сотрудники } \\
\text { правоохранит. } \\
\text { органов }\end{array}$} & \multicolumn{2}{|c|}{ сдл } \\
\hline & & $\begin{array}{l}\Phi \\
\frac{1}{2} \\
\frac{1}{0} \\
\frac{0}{0}\end{array}$ & $\begin{array}{l}\dot{5} \\
\frac{5}{5} \\
\dot{5} \\
\dot{5}\end{array}$ & $\begin{array}{l}\Phi \\
\frac{1}{2} \\
\frac{10}{0} \\
\frac{0}{0}\end{array}$ & \begin{tabular}{l}
$\dot{5}$ \\
\multicolumn{5}{c}{} \\
$\dot{5}$ \\
$\dot{U}$
\end{tabular} & 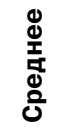 & \begin{tabular}{l}
$\dot{5}$ \\
\multicolumn{2}{c}{} \\
$\dot{5}$ \\
$\dot{5}$
\end{tabular} \\
\hline 20 & $\begin{array}{l}\text { Может ли население по- } \\
\text { влиять на Ваше поведение } \\
\text { относительно ПоД/ФТ тем } \\
\text { или иным способом }\end{array}$ & 1,8 & 0,957 & 1,6 & 0,447 & 1,1 & 0,333 \\
\hline 21 & $\begin{array}{l}\text { Имеет ли общественный } \\
\text { контроль в сфере ПОД/ФТ } \\
\text { реальное влияние на Вас }\end{array}$ & 2,3 & 3,862 & 4,0 & 2,449 & 3,2 & 3,632 \\
\hline 22 & $\begin{array}{l}\text { Существует ли в Вашей } \\
\text { организации руководство } \\
\text { в сфере ПОД/ФТ, помимо } \\
\text { государственных (напри- } \\
\text { мер, саморегулируемая } \\
\text { организация, финан- } \\
\text { совый аудит, кодексы } \\
\text { поведения, сертификация, } \\
\text { лицензирование }\end{array}$ & 3,0 & 0,000 & 1,8 & 1,095 & 2,9 & 0,333 \\
\hline 23 & $\begin{array}{l}\text { Способствует ли такое } \\
\text { руководство в сфере ПОД/ } \\
\text { ФТ лучшему соблюдению } \\
\text { закона о ПОД/ФТ }\end{array}$ & 3,0 & 0,000 & 2,4 & 0,548 & 2,7 & 0,707 \\
\hline 24 & $\begin{array}{l}\text { Рассматриваете ли Вы } \\
\text { такое руководство как до- } \\
\text { полнительную форму кон- } \\
\text { троля в сфере о ПОД/ФТ }\end{array}$ & 3,0 & 0,000 & 2,8 & 0,447 & 2,9 & 0,333 \\
\hline 25 & $\begin{array}{l}\text { Оказывает ли такое руко- } \\
\text { водство в сфере ПОД/ФТ } \\
\text { реальное влияние на Вас }\end{array}$ & 9,5 & 1,000 & 3,0 & 3,082 & 7,3 & 3,122 \\
\hline 26 & $\begin{array}{l}\text { По Вашей оценке, насе- } \\
\text { ление в целом склонно } \\
\text { ставить В известность } \\
\text { контролирующие органы } \\
\text { при обнаружении правона- } \\
\text { рушения в сфере ПОД/ФТ }\end{array}$ & 1,0 & 0,000 & 1,0 & 0,000 & 2,1 & 0,928 \\
\hline 27 & $\begin{array}{l}\text { По Вашей оценке, руко- } \\
\text { водители организаций, } \\
\text { в целом склонны ставить } \\
\text { в известность контроли- } \\
\text { рующие органы при обна- } \\
\text { ружении правонарушения } \\
\text { в сфере ПОД/ФТ }\end{array}$ & 1,5 & 1,000 & 1,0 & 0,000 & 2,1 & 0,928 \\
\hline
\end{tabular}




\begin{tabular}{|c|c|c|c|c|c|c|c|}
\hline \multirow[b]{2}{*}{ № } & \multirow[b]{2}{*}{ Переменные } & \multicolumn{2}{|c|}{$\begin{array}{l}\text { Специалисты ЦБ } \\
\text { РФ }\end{array}$} & \multicolumn{2}{|c|}{$\begin{array}{c}\text { Сотрудники } \\
\text { правоохранит. } \\
\text { органов } \\
\end{array}$} & \multicolumn{2}{|c|}{ сдл } \\
\hline & & 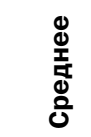 & $\begin{array}{l}\dot{5} \\
\text { 5. } \\
\dot{5}\end{array}$ & 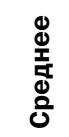 & $\begin{array}{l}5 \\
5 \\
5 \\
5 \\
5\end{array}$ & 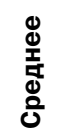 & 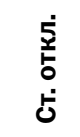 \\
\hline 28 & $\begin{array}{l}\text { Считаете ли Вы, что люди } \\
\text { в основном знают, какому } \\
\text { именно контролирующему } \\
\text { органу следует сообщить } \\
\text { о правонарушении в сфере } \\
\text { пОД/ФТ }\end{array}$ & 1,0 & 0,000 & 1,2 & 0,447 & 2,0 & 1,000 \\
\hline III & \multicolumn{7}{|c|}{$\begin{array}{l}\text { Эффективность надзорно-контрольной деятельности } \\
\text { за соблюдением закона о ПОД/ФТ/ФРОМУ }\end{array}$} \\
\hline 29 & $\begin{array}{l}\text { Оцените вероятность того, } \\
\text { что документы финансовых } \\
\text { и нефинансовых органи- } \\
\text { заций и профессий будут } \\
\text { ежегодно проверены }\end{array}$ & 6,5 & 1,000 & 3,4 & 2,881 & 4,8 & 3,930 \\
\hline 30 & $\begin{array}{l}\text { Оцените вероятность } \\
\text { проведения инспекций } \\
\text { по ПОД/ФТ на местах }\end{array}$ & 4,0 & 3,464 & 4,0 & 2,550 & 4,3 & 3,969 \\
\hline 31 & $\begin{array}{l}\text { Достаточно ли легко обна- } \\
\text { ружить правонарушение } \\
\text { в сфере ПОД/ФТ при про- } \\
\text { верке документов }\end{array}$ & 5,0 & 2,449 & 5,0 & 1,581 & 4,1 & 3,408 \\
\hline 32 & $\begin{array}{l}\text { Достаточно ли сложно } \\
\text { фальсифицировать } \\
\text { документы }\end{array}$ & 2,3 & 0,957 & 1,6 & 0,894 & 2,0 & 0,866 \\
\hline 33 & $\begin{array}{l}\text { Какова, на Ваш взгляд, } \\
\text { вероятность обнаружения } \\
\text { правонарушений в сфере } \\
\text { пОД/ФТ при дистанцион- } \\
\text { ной проверке }\end{array}$ & 8,8 & 0,500 & 7,8 & 1,304 & 5,3 & 3,000 \\
\hline 34 & $\begin{array}{l}\text { Достаточно ли легко, } \\
\text { по Вашему мнению, для } \\
\text { инспекторов обнаружить } \\
\text { правонарушение по ПоД/ } \\
\text { ФТ }\end{array}$ & 2,8 & 0,500 & 2,2 & 1,095 & 2,2 & 0,833 \\
\hline 35 & $\begin{array}{l}\text { Имеют ли правонарушения } \\
\text { по ПОД/ФТ какие-либо } \\
\text { ограничения по времени } \\
\text { и/или месту (локализации) }\end{array}$ & 1,8 & 0,957 & 1,0 & 0,000 & 2,3 & 0,866 \\
\hline 36 & $\begin{array}{l}\text { Достаточно ли, на Ваш } \\
\text { взгляд, техническое осна- } \\
\text { щение инспекторов для } \\
\text { того, чтобы выявить право- } \\
\text { нарушение по поД/ФТ }\end{array}$ & 3,0 & 0,000 & 2,4 & 0,894 & 2,1 & 0,782 \\
\hline
\end{tabular}




\begin{tabular}{|c|c|c|c|c|c|c|c|}
\hline \multirow[b]{2}{*}{ № } & \multirow[b]{2}{*}{ Переменные } & \multicolumn{2}{|c|}{$\begin{array}{c}\text { Специалисты ЦБ } \\
\text { РФ }\end{array}$} & \multicolumn{2}{|c|}{$\begin{array}{c}\text { Сотрудники } \\
\text { правоохранит. } \\
\text { органов }\end{array}$} & \multicolumn{2}{|c|}{ сдл } \\
\hline & & $\begin{array}{l}\frac{0}{0} \\
\frac{\Phi}{1} \\
\frac{1}{0} \\
\frac{0}{0}\end{array}$ & $\begin{array}{l}\dot{5} \\
\text { 5̇ } \\
\dot{5} \\
\dot{b}\end{array}$ & 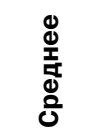 & $\begin{array}{l}5 \\
5 \\
5 \\
5\end{array}$ & $\begin{array}{l}\frac{\Xi}{\Phi} \\
\frac{1}{5} \\
\frac{5}{0} \\
0\end{array}$ & \begin{tabular}{l}
$\dot{5}$ \\
\multicolumn{2}{c}{} \\
$\dot{5}$ \\
$\dot{0}$
\end{tabular} \\
\hline 37 & $\begin{array}{l}\text { Знают ли правонаруши- } \\
\text { тели в сфере ПОД/ФТ, что } \\
\text { они всегда будут инспекти- } \\
\text { роваться чаще, чем те, кто } \\
\text { соблюдает закон о ПоД/ФТ }\end{array}$ & 2,5 & 0,577 & 1,8 & 1,095 & 2,7 & 0,500 \\
\hline 38 & $\begin{array}{l}\text { Как Вы считаете, целевые } \\
\text { инспекции в сфере Под/ } \\
\text { ФТ обнаруживают больше } \\
\text { правонарушителей, чем } \\
\text { дистанционные }\end{array}$ & 1,8 & 0,957 & 3,0 & 0,000 & 2,8 & 0,441 \\
\hline 39 & $\begin{array}{l}\text { Оцените вероятность при- } \\
\text { менения санкций в случае } \\
\text { обнаружения правонару- } \\
\text { шений в сфере ПОД/ФТ }\end{array}$ & 9,5 & 1,000 & 9,2 & 0,837 & 8,1 & 2,147 \\
\hline 40 & $\begin{array}{l}\text { По Вашей оценке, доста- } \\
\text { точно ли легко доказать } \\
\text { правонарушение в сфере } \\
\text { поД/ФТ }\end{array}$ & 1,3 & 0,500 & 2,4 & 0,894 & 2,0 & 0,866 \\
\hline 41 & $\begin{array}{l}\text { Знаете ли Вы, какие санк- } \\
\text { ции могу применяться при } \\
\text { совершении правонаруше- } \\
\text { ния по ПОД/ФТ }\end{array}$ & 3,0 & 0,000 & 3,0 & 0,000 & 3,0 & 0,000 \\
\hline 42 & $\begin{array}{l}\text { Считаете ли Вы такие санк- } \\
\text { ции достаточно суровыми }\end{array}$ & 2,0 & 1,155 & 1,4 & 0,894 & 2,6 & 0,882 \\
\hline 43 & $\begin{array}{l}\text { Насколько быстро испол- } \\
\text { няется наказание за нару- } \\
\text { шения по ПОД/ФТ }\end{array}$ & 6,5 & 0,577 & 3,8 & 1,789 & 6,2 & 3,930 \\
\hline 44 & $\begin{array}{l}\text { Применение санкций } \\
\text { имеет какие-либо допол- } \\
\text { нительные прямые или } \\
\text { косвенные неудобства для } \\
\text { нарушителя по ПОД/ФТ }\end{array}$ & 3,0 & 0,000 & 3,0 & 0,000 & 0,9 & 0,333 \\
\hline & Сумма баллов & 175,4 & - & 167,4 & - & 157,8 & - \\
\hline
\end{tabular}

Переменная имеет десятибалльную шкалу.

Переменная имеет трехбалльную шкалу. 